\title{
Distribution of calcium, magnesium, phosphorus, zinc, manganese, copper and iron between the soluble and colloidal phases of ewe's and goat's milk
}

\author{
MA de la Fuente ${ }^{1}$, A Olano ${ }^{2}$, M Juárez ${ }^{1}$ \\ ${ }^{I}$ Instituto del Frío (CSIC), Ciudad Universitaria s/n, 28040 Madrid; \\ ${ }^{2}$ Instituto de Fermentaciones Industriales (CSIC), Juan de la Cierva 3, 28006 Madrid, Spain
}

(Received 2 December 1996; accepted 24 March 1997)

\begin{abstract}
Summary - This paper examines the distribution of main elements (calcium, magnesium and phosphorus) and microelements (zinc, iron, manganese and copper) between the soluble and colloidal phases of ewe's and goat's milk. The percentages of calcium, magnesium and phosphorus were higher in the soluble phase of goat's milk $(32.8,66.4$ and $38.6 \%$ respectively) than in that of ewe's milk $(20.8,56$ and $34.8 \%$ respectively). In both species most of the zinc (91.6\% in ewe and $87.5 \%$ in goat) and the manganese ( $93 \%$ and $89 \%$ in ewe and goat respectively) were found in the micellar fraction. The distribution of iron and copper differed more. The soluble phase of ewe's milk contained $28.5 \%$ iron and the soluble phase of goat's milk $44.3 \%$. Ewe's milk contained more soluble copper $(33.3 \%)$ than did goat's milk $(18.1 \%)$.
\end{abstract}

ewe's milk / goat's milk / mineral composition

Résumé - Distribution du calcium, du magnésium, du phosphore, du zinc, du manganèse, du cuivre et du fer entre phases soluble et collö̈dale des laits de brebis et de chèvre. La distribution entre les phases soluble et colloïdale des éléments minéraux majoritaires (calcium, magnésium et phosphore) et des microéléments (zinc, fer, manganèse et cuivre) a été étudiée dans les laits de brebis et de chèvre. Les pourcentages de calcium, de magnésium et de phosphore solubles (respectivement $32,8,66,4$ et 38,6 ) se sont révélés être plus élevés dans le lait caprin que dans le lait ovin (respectivement $20,8,56,0$ et 34,8$)$. Dans les deux espèces, la majorité du zinc $(91,6 \%$ chez la brebis et $87,5 \%$ chez la chèvre) et du manganèse (respectivement $93 \%$ et $89 \%$ chez la brebis et chez la chèvre) se trouve dans la fraction micellaire. En revanche, les distributions du fer et du cuivre sont sensiblement différentes. La phase soluble du lait de brebis contient $28,5 \%$ de fer et celle du lait de chèvre $44,3 \%$. Le lait de brebis est plus riche en cuivre soluble $(33,3 \%)$ que le lait de chèvre $(18,1 \%)$.

lait de brebis / lait de chèvre / composition minérale 


\section{INTRODUCTION}

There is currently considerable growth in the economic importance of ewe's and goat's milk, particularly in Mediterranean countries as products derived from them mainly cheeses - gain in popularity. Although overall mineral composition has been studied, there is very little information available on the distribution of salts between the soluble and colloidal phases of milk from these species as compared to cow's and buffalo's milk.

For goat's milk there are data available on the calcium and magnesium content of the soluble and colloidal phases, particularly in Asian breeds found in India, where calcium levels in the casein micelles have been found to differ from those in cow's milk, with higher colloidal calcium and magnesium levels (Pachauri and Gupta, 1982; Singh and Singh, 1983). As regards the distribution of microelements, only isolated studies are available on the distribution of zinc between the two phases (Swamy and Mathur, 1985; Kiely et al, 1992). These indicate that zinc is bound to colloidal calcium phosphate in a slightly higher proportion than in cow's milk; there is no information on the other trace elements except for iron (Swamy and Mathur, 1983).

Data on ewe's milk is even more scarce. The only findings published have been on the balance of main elements (calcium, magnesium and phosphorus) (O'Connor and Fox, 1977; Holt and Jenness, 1984; Polychroniadou and Vafopoulou, 1986). The most striking aspect of these findings is the difference in the distribution of calcium in goat's and ewe's milks. Percentages of calcium in the soluble phase of ewe's milk are lower than in milk from other species.

Trace elements are part of essential substances such as hemoglobin and vitamin $B_{12}$, and many enzymes require specific metallic activators. The increased awareness of the relation between dietary trace elements and health has contributed to the interest for these nutrients. The chemical form of a nutrient may influence bioavailability: free forms like soluble ions are well absorbed, whereas those that are bound are often poorly absorbed. This study was undertaken to determine the distribution of calcium, magnesium, phosphorus, zinc, manganese, iron and copper in ewe's and goat's milk, with particular reference to trace elements as a contribution to the knowledge of nutritional characteristics of these types of milk and to the retention of these elements in the curd during cheesemaking.

\section{MATERIALS AND METHODS}

\section{Samples and reagents}

The raw ewe's and goat's milks used came from large-volume tanks (2000-4000 L) and were taken from different flocks or herds in middle lactation (each of at least 100 heads) from farms in the Madrid Region. Milk was carried to the laboratory in isothermal containers within $1 \mathrm{~h}$ of milking. $\mathrm{pH}$ of milk samples varied within the range $6.60-6.68$. Ten samples were taken from the milk of each of the two species and all samples were analyzed in quintuplicate.

All reagents were of the highest possible purity and at least analytical grade. Distilled water with $18 \mathrm{M} \Omega \mathrm{cm}$ resistance was used in the preparation of all sample and standard solutions.

\section{Measuring apparatus}

The determination of phosphorus was carried out using an UV-visible spectrometer, Model Lambda 15 (Perkin-Elmer, Norwalk, USA) at $750 \mathrm{~nm}$.

A model Zeeman 5100 PC atomic absorption spectrometer (Perkin-Elmer, Norwalk, USA) with an HGA-600 graphite furnace, Zeeman background correction and AS-60 autosampler was used for the rest of the elements. 


\section{Methods of analysis}

The soluble phase was separated by high-speed centrifugation as described by De la Fuente et al (1996) in a Sorvall Combi Plus ultracentrifuge (Wilmington, USA): $30 \mathrm{~mL}$ of milk was centrifuged $(100000 \mathrm{~g})$ at $20^{\circ} \mathrm{C}$ for $1 \mathrm{~h}$ using a $50-\mathrm{RT}$ 1250 rotor. The supernatant was carefully removed and vacuum-filtered through Whatman 40 paper.

Calcium and magnesium were measured by flame atomic absorption spectrometry and phosphorus was estimated colorimetrically by a molybdenum blue method after sample digestion in a microwave oven according to De la Fuente et al (1996). $\mathrm{Mn}, \mathrm{Zn}, \mathrm{Fe}$ and $\mathrm{Cu}$ were measured by graphite furnace atomic absorption spectrometry using the procedures proposed by De la Fuente et al $(1995 a, b)$.

\section{RESULTS AND DISCUSSION}

Table I shows the maxima, minima and averages of total and soluble $\mathrm{Ca}, \mathrm{Mg}, \mathrm{P}, \mathrm{Mn}$, $\mathrm{Zn}, \mathrm{Fe}$ and copper in the ewe's and goat's milk samples. Percentages of $\mathrm{Ca}, \mathrm{Mg}$ and $\mathrm{P}$ in the soluble phase of goat's milk were $32.8 \%, 66.4 \%$ and $38.6 \%$ respectively. Previous studies on goat's milk from Asian breeds (Pachauri and Gupta, 1982; Agarwal and Gupta, 1984) had reported soluble $\mathrm{Ca}$ close to $30 \%$. In European breeds percentages range from $30 \%$ (Remeuf, 1993) to $37.7 \%$ (O'Connor and Fox, 1977). The level of $\mathrm{Mg}$ in the present assay (66.4\%) was close to that found in previous studies $(70 \%)$. $P$ in the soluble phase was $38.6 \%$ of total $\mathrm{P}$, which is within the wide spectrum of variation reported in the literature.

Percentages of $\mathrm{Ca}, \mathrm{Mg}$ and $\mathrm{P}$ in the soluble phase of ewe's milk were 20.8, 56 and 34.8 respectively. Polychroniadou and Vafopoulou (1986) found $25 \%$ of Ca, $64 \%$ of $\mathrm{Mg}$ and $38 \%$ of $\mathrm{P}$ remaining in the soluble phase. Pellegrini et al (1994) reported levels of soluble calcium and phosphorus of $20-25 \%$ and $35-40 \%$ respectively

Table I. Total and soluble contents $\left(\mathrm{mg} . \mathrm{L}^{-1}\right)$ of calcium, magnesium, phosphorus, zinc, iron, copper and manganese in ewe's and goat's milks.

Concentration totale et soluble $\left(m g . L^{-1}\right)$ en calcium, magnésium, phosphore, zinc, manganèse, fer et cuivre dans les laits de brebis et de chèvre.

\begin{tabular}{lccccccc}
\hline Element & \multicolumn{3}{c}{ Ewe } & & \multicolumn{3}{c}{ Goat } \\
\cline { 2 - 3 } \cline { 7 - 8 } & Mean & Maximum & Minimum & & Mean & Maximum & Minimum \\
\hline Ca total & 2156 & 2385 & 1983 & & 1468 & 1586 & 1343 \\
Ca soluble & 448 & 474 & 406 & & 482 & 529 & 404 \\
Mg total & 193 & 212 & 175 & & 122 & 144 & 110 \\
Mg soluble & 108 & 118 & 97 & & 81 & 96 & 71 \\
P total & 1456 & 1582 & 1398 & & 872 & 954 & 792 \\
P soluble & 507 & 540 & 435 & & 337 & 363 & 318 \\
Zn total & 8.03 & 8.56 & 6.78 & & 4.64 & 5.23 & 4.14 \\
Zn soluble & 0.67 & 0.87 & 0.47 & & 0.58 & 0.62 & 0.42 \\
Fe total & 1.16 & 1.42 & 0.96 & & 0.63 & 0.81 & 0.54 \\
Fe soluble & 0.33 & 0.43 & 0.26 & & 0.28 & 0.35 & 0.25 \\
Cu total & 0.41 & 0.48 & 0.32 & & 0.28 & 0.32 & 0.22 \\
Cu soluble & 0.14 & 0.18 & 0.11 & & 0.05 & 0.06 & 0.04 \\
Mn total & 0.059 & 0.066 & 0.049 & & 0.034 & 0.044 & 0.023 \\
Mn soluble & 0.004 & 0.005 & 0.003 & & 0.004 & 0.006 & 0.00 \\
\hline
\end{tabular}


in ewe's milk collected in the Roquefort area throughout the lactation period.

The differences between these results and the findings published in the literature may be due to natural variation determined by genetic or environmental factors.

Total manganese, iron, copper and zinc contents were within the range derived from previous published values. As to distribution between the two phases, the percentages of each microelement in these milks are variable. Since there are very few studies of this kind on milk other than cow's milk suitable for comparative purposes, cow's milk is best used for reference.

Most of the zinc was found in the insoluble fraction in both ewe's milk (91.6\%) and goat's milk ( $87.5 \%)$. This is comparable to the distribution found in previous studies on bovine milk. Since the percentages of zinc bound to the lipid fraction are very low, at least as determined in cow's milk (Fransson and Lönnerdal, 1983; Sandström et al, 1983; Renner et al, 1989), casein is presumably the principal zinc-binding ligand in ewe's and goat's milk. As a result of this distribution, the bioavailability of zinc is much lower than in human milk. In the latter, zinc is largely found in the soluble phase bound to citrate molecules (Lönnerdal et al, 1981; Martin et al, 1984) and lactoferrin molecules (Blakeborough et al, 1983; Flynn and Power, 1985 ) and is hence more readily absorbed by the intestinal tract of new-born babies. Recent studies (Shen et al, 1995) in human, cow's, goat's and sheep's milks also showed a considerable higher zinc bioavailability for human milk than for the other species.

Swamy and Mathur (1985) studied milk from Asian goat breeds and recorded percentages of zinc similar to those found in the present work. More recently, Kiely et al (1992) estimated that $66 \%$ of the zinc in ewe's milk and $72 \%$ of the zinc in goat's milk was bound to the micellar complex. The reason for such low figures could lie in the fractionating procedure, which included an acidification and a dialyzing stage. For studies of this kind it is best to use methods which cause the least possible disturbance of the micellar structure, such as ultracentrifugation. Methods which include isolation by acidic precipitation are unsuitable, as alteration of the $\mathrm{pH}$ causes redistribution of the elements that are to be analyzed, so that the original distribution is lost (Fransson and Lönnerdal, 1983). And again, it seems clear (Singh et al, 1989; De la Fuente et al, 1996) that separation by dialysis favors the passage of minerals, particularly calcium and zinc, from the micellar complex to the soluble phase.

Manganese was found largely in micellar phase. The percentage of this element in the soluble phase was $7 \%$ in ewe's milk and $11 \%$ in goat's milk. No data on these species were found in the literature for comparison with our results; the few studies published on distribution of manganese refer to cow's milk. Brulé and Fauquant (1982) reported over $95 \%$ of manganese in the casein fraction, while Lönnerdal et al (1983) found $83 \%$ bonded to the caseins. Although Flynn and Power (1985) suggested that fat globules could bind part of this mineral, most studies report manganese concentrations of a scanty $1 \%$ of total content was linked to the lipid fraction (Lönnerdal et al, 1983).

Higher percentages of copper than manganese or zinc were detected in the soluble phase of ewe's (34\%) and goat's milk $(18 \%)$. Although the distribution of copper has not been documented for these species, the available data on cow's milk highlight the importance of caseins as copper-binding ligands. There is however no agreement as to the percentage of copper bound to casein. The fluctuation in findings can be very wide depending on the sources: $35 \%$ (FIL, 1992), 44\% (Renner et al, 1989) and even values as high as $70-75 \%$ (Brulé and Fauquant, 1982). One of the factors contributing to so wide a disparity is the distribution of copper within the fatty fraction. The fat-bound copper is so distributed that most of it is associated with the outer fat globule membrane (Fransson and Lönnerdal, 1983 ) and can readily pass into the serum 
(FIL, 1992). In this way the soluble fraction would be copper-enriched, more so ewe's milk owing to its higher fat content.

The reason for the difference in percentages of soluble copper in ewe's and goat's milk lies in their different compositions. Most of the copper is bound to ligands of low molecular mass, largely citrate (Martin et al, 1984) with a very small percentage, not more than $8 \%$, bound to the serum proteins (Brulé and Fauquant, 1982; Renner et al, 1989). Although these data are taken from studies in cow's milk, Martin et al (1981) reported earlier that citrate acted as a copper-binding ligand in goat's milk as well. Brulé and Fauquant (1982) found that adding citrate to the milk encouraged a shift of copper from the protein to the serum fraction. One of the reasons for the higher proportion of soluble copper in ewe's milk could be its higher citrate content (Storry et al, 1983), since most of this molecule is found in the serum fraction. And yet another possible cause of differences in distribution is the high affinity for copper displayed by $\beta$ casein (Brulé and Fauquant, 1982). As this is the most abundant protein in goat micelles, it seems that it influences the retention of copper in the colloidal phase, naturally causing a reduction in the soluble phase.

Along with copper, iron was the microelement found the most abundant in the soluble phases of the milk samples. For goat's milk, the average iron percentage in the soluble phase was $44 \%$ of total content comparable to the concentration reported by Swamy and Mathur (1983) in milk from the Beetal breed. These authors found that one-third of the iron was bound to the lipid fraction and $42 \%$ to the serum components. In ewe's milk, the percentage of soluble iron was lower $(28.5 \%)$, perhaps because of the higher fat content in ewe's milk. Of all the elements considered here, iron is probably the one that was bound in the highest proportion to the lipid fraction. The percentages given in the literature for bovine milk range from $14 \%$ to $50 \%$ (Lönnerdal et al, 1981; Flynn and Power, 1985; Renner et al, 1989; FIL, 1992), although in other ruminant species the dis- tribution may be different. As regards iron content in the casein fraction, $\alpha_{\mathrm{s}}$-casein is an important iron-binding ligand. Hegenauer et al (1979) showed that $\alpha_{\mathrm{s}}$-casein is the protein that binds most iron in cow's milk, and that it are the phosphate groups which are responsible for the bond. Brulé and Fauquant (1982) took up this point and argued that the caseins with most phosphoserine residue would be those capable of binding most iron atoms. This could then help to account for the higher levels of soluble iron found in goat's milk than in ewe's milk. The concentration of $\alpha_{\mathrm{s}}$-casein is higher in ewe's milk than in goat's milk (Storry et al, 1983; Law et al, 1993) and therefore the iron content in the soluble fraction should be lower. From the literature data, it is very likely that part of the iron in the soluble fraction is bound to ligands of low molecular mass, while another part is bound to serum proteins, especially lactoferrin (Fransson and Lönnerdal, 1983; FIL, 1992).

\section{CONCLUSIONS}

The distributions of zinc and manganese in ewe's and goat's milks (around 90\% in the micellar fraction) are similar to those reported in cow's milk.

Percentages of micellar iron and copper differ in both species (56 and $82 \%$ in goat's milk against 72 and $67 \%$ in ewe's milk respectively). In spite of the lower total iron contents in goat's milk with respect to ewe's milk, both types of milk have similar quantities of soluble iron.

These data afford useful information as to the assessment of mineral biodisponibility of these types of milk. Moreover, since ewe's and goat's milk are mainly used in cheesemaking and most of the soluble elements are lost in the whey during manufacture, the knowledge of trace elements distribution would allow to evaluate the influence of milk composition on the trace mineral content in cheese. 


\section{ACKNOWLEDGMENTS}

The authors acknowledge financial support for this research project (ALI93-0005-CP) from the Comisión Interministerial de Ciencia y Tecnología (CICyT). We also thank G Guerrero for his assistance with the spectrometric measurements.

\section{REFERENCES}

Agàrwal AC, Gupta MP (1984) Influence of heat, urea and calcium-sequestering agents on the physicochemical state of calcium and magnesium in goat milk. Indian J Anim Sci 54, 326-331

Blakeborough P, Salter DN, Gurr MI (1983) Zinc binding in cow's milk and human milk. Biochem J 209 , 505-512

Brulé G, Fauquant J (1982) Interactions des protéines du lait et des oligoéléments. Lait 62, 323-331

De la Fuente MA, Guerrero G, Juárez M (1995a). Manganese and zinc analysis in milk by microwave oven digestion and platform graphite furnace atomic absorption spectrometry. I Agric Food Chem 43, 2406-2410

De la Fuente MA, Guerrero G, Juárez M (1995b) Determination of copper in skim milk by GFAAS using palladium-magnesium modifier and L'vov platform. At Spectrosc 5, 219-223

De la Fuente MA, Fontecha J, Juárez M (1996) Partition of main and trace minerals in milk: effect of ultracentrifugation, rennet coagulation and dialysis on soluble phase separation. J Agric Food Chem 44, 1988-1992

FIL (Fédération internationale de laiterie) (1992) Trace elements in milk and dairy products. Bull Int Dairy Fed 278, 16-30

Flynn A, Power P (1985) Nutritional aspects of minerals in bovine and human milks. In: Developments in Dairy Chemistry 3 (Fox PF, ed), Elsevier, London, 183-215

Fransson GB, Lönnerdal B (1983) Distribution of trace elements and minerals in human and cow's milk. Pediatr Res 17, 912-915

Hegenauer J, Saltman P, Ludwig D, Ripley L, Ley A (1979) Iron-supplemented cow milk. Identification and spectral properties of iron bound to casein micelles. J Agric Food Chem 27, 1294-1301

Holt C, Jenness R (1984) Interrelationships of constituents and partition of salts in milk samples from eight species. Comp Biochem Physiol 77A, 275-282

Kiely LJ, Flynn A, Fox PF (1992) Association of zinc with colloidal calcium phosphate in bovine and non-bovine milks. J Dairy Sci 75 (Suppl 1), 105

Law AJR, Papoff CM, Dalgleish DG, Campus RL (1992) Quantitative fractionation of ovine casein by cation-exchange FPLC. Milchwissenschaft 47 , 279-282

Lönnerdal B, Keen CL, Hurley LS (1981) Iron, copper, zinc and manganese in milk. Annu Rev Nutr 1 , 149-174

Lönnerdal B, Keen CL, Hurley LS (1983) Manganese binding in human milk and cow's milk - an effect on bioavailability. Fed Proc 42,926

Martin MT, Licklider KF, Brushmiller JG, Jacobs FA (1981) Detection of low molecular weight copper (II) and zinc (II) binding ligands in ultrafiltered milks - the citrate connection. J Inorg Biochem 15 , $55-65$

Martin MT, Jacobs FA, Brushmiller JG (1984) Identification of copper- and zinc-binding ligands in human and bovine milk. J Nutr 114, 869-879

O'Connor P, Fox PF (1977) The proteins and salts of some non-bovine milks. J Dairy Res 44, 607-609

Pachauri DK, Gupta MP (1982) Note on the physicochemical state of calcium and magnesium in goat's milk. Indian J Anim Sci 52, 1271-1272

Pellegrini O, Remeuf F, Rivemale M (1994) Evolution des caractéristiques physico-chimiques et des paramètres de coagulation du lait de brebis collecté dans la région de Roquefort. Lait 74, 425-442

Polychroniadou A, Vafopoulou A (1986) Salt distribution between the colloidal and soluble phases of ewes' milk, I Dairy Res 53, 353-358

Remeuf F (1993) Influence du polymorphisme génétique de la caséine $\alpha_{s 1}$ caprine sur les caractéristiques physico-chimiques et technologiques du lait. Lait 73, 549-557

Renner E, Schaafsma G, Scott KJ (1989) Micronutrients in milk. In: Micronutrients in milk and milkbased food products (Renner E, ed) Elsevier, New York, 1-70

Sandström B, Keen CL, Lönnerdal B (1983) An experimental model for studies of zinc bioavailability from milk and infant formulas using extrinsic labelling. Am J Chem Nutr 38, 420-428

Shen L, Robberecht H, Van Dael P, Deelstra H (1995) Estimation of the bioavailability of zinc and calcium from human, cow's, goat's, and sheep's milk by an in vitro method. Biol Tr Elem Res 49. $107-118$

Singh H, Flynn A, Fox PF (1989) Zinc binding in bovine milk. J Dairy Res 56, 249-263

Singh VB, Singh SN (1983) Salt balance of milk of four Indian goat breeds during lactation and its relation with the stability. Asian J Dairy Res 2, 8-18

Storry JE, Grandison AS, Millard D, Owen AJ, Ford GD (1983) chemical composition and coagulating properties of renneted milks from different breeds and species of ruminant. I Dairy Res 50, 215-229

Swamy SAN, Mathur ON (1983) Studies on iron content in goat's milk. Asian J Dairy Res 2, 201-204

Swamy SAN, Mathur ON (1985) Studies on zinc content of goat's milk. Asian J Dairy Res 3, 135-138 